\title{
CORRELATION BETWEEN ERECTILE DYSFUNCTION AND SEVERITY SYMPTOMS OF DEPRESSION THROUGH THE ROLE OF SELF-ESTEEM AND PSYCHOSOCIAL STRESSOR
}

\author{
Sirait HSP*, Juniar S**, Tanojo TD*** \\ * Dokter umum, peserta PPDS I Psikiatri FK Universitas Airlangga / RSUD Dr. Soetomo Surabaya / RSUD Kabupaten Bekasi \\ ** Psikiater Konsultan, Staf Pengajar Departemen / SMF Ilmu Kedokteran Jiwa FK Universitas Airlangga / RSUD Dr. Soetomo Surabaya \\ *** Dokter Spesialis Andrologi, Staf Pengajar Departemen / SMF Andrologi FK Universitas Airlangga / RSUD Dr.Soetomo Surabaya
}

\begin{abstract}
Background: Twenty two percent of men aged over 40 years suffer from erectile dysfunction moderate to severe degree. Twelve to twenty eight percent of men with erectile dysfunction report an impact on the relationship with the partner, body image, lowered self-esteem that might be a psychosocial stressor that cause symptoms of depression. Treatment of erectile dysfunction holistically is expected to improve a better life.

Objective: This study analyzed the correlation between erectile dysfunction and severity of depressive symptoms through the role of self-esteem and psychosocial stressors on patients with erectile dysfunction in Andrology Outpatient Clinic of Dr. Soetomo General Hospital.

Methods: This study using correlation analytic with cross sectional design. Research subject were patients who have erectile dysfunction in Andrology Outpatient Clinic of Dr. Soetomo General Hospital, collected using consecutive sampling. The research instruments used were The International Index of Erectile Function-5, Holmes-Rahe, Self-Esteem Rosenberg and Beck Depression Inventory

Results: Thirty eight research subjects met the inclusion criteria. Statistical analysis revealed erectile dysfunction correlated with self-esteem ( $p=0.016 r=0,388)$, no correlation between self-esteem and the severity of depressive symptoms $(p=0.116 r=0,259)$, psychosocial stressors correlated with the severity of depressive symptoms ( $p=0.001 \quad r=0,001)$, erectile dysfunction correlated with the severity of depressive symptoms ( $p=0,000 \quad r=-0,559)$

Conclusion: This study found correlation between erectile dysfunction and severity of depressive symptoms both directly, but in this case does not involve the role of self-esteem and psychosocial stressors
\end{abstract}

Keywords: erectile dysfunction, depression, self-esteem, psychosocial stressors

Corresponding author: Hendriks S.P Sirait, dr.

Dep/SMF Kedokteran Jiwa FK UNAIR/RSUD Dr.Soetomo Surabaya/RSUD Kabupaten Bekasi

HP: 08129429408 | email: hendrikhensza@gmail.com 


\section{PENDAHULUAN}

The Massachusetts Male Aging Study di Amerika Serikat melaporkan prevalensi disfungsi ereksi pada usia 40-70 tahun (dengan berbagai derajat disfungsi ereksi) sebesar 52\%, dengan peningkatan prevalensi 5\% tiap sepuluh tahun, hingga terjadi disfungsi ereksi derajat berat [1]. Suatu penelitian di Asia yang dilakukan sejak tahun 1986-2006 mengatakan prevalensi disfungsi ereksi di Asia sendiri antara 2-88\%, Filipina memiliki prevalensi tertinggi sebesar 33\%, Thailand 29\%, Malaysia 28\%, Korea 18\%, Jepang $13 \%$, Indonesia $11 \%$ dan terendah Singapura $2 \%$ [2]. Kemampuan ereksi seorang pria melambangkan simbol stamina dan status sosial seorang pria [3]. Pria yang mengalami disfungsi ereksi akan mengalami kerugian secara materi dan psikologis. Kerugian tersebut menimbulkan berbagai masalah psikososial seperti, gangguan citra tubuh dan kepercayaan diri (self-esteem), depresi, hingga penurunan kualitas hidup seseorang [4]. Saat mereka tidak dapat tampil "perkasa" dalam berhubungan seksual dengan pasangan, kepercayaan diri mereka akan berkurang, yang nantinya berakhir dalam kondisi depresi $[5,6]$.

Suatu penelitian di Nigeria mengatakan $15 \%$ responden yang mengalami disfungsi ereksi berhubungan dengan terjadinya stresor psikososial seperti berkurangnya kemampuan dalam bekerja, pendapatan dan bersosialisasi [7]. Bahkan penelitian lain menunjukkan bahwa 12-28\% pria dengan disfungsi ereksi memiliki masalah dalam hal keintiman atau kemesraan dengan pasangan [5]. Demikian juga dengan bertambah usia seseorang, maka stresor psikososial akan meningkat dan mempengaruhi kinerja seseorang dalam pekerjaan, pendapatan (keuangan) dan keharmonisan dengan pasangan, sehingga jika stresor tersebut terus berlangsung dalam jangka panjang, maka orang tersebut akan mengalami kelelahan mental dan pada akhirnya akan memasuki kondisi depresi [8,9]. Penelitian lain menunjukkan $25 \%$ pria yang mengalami disfungsi ereksi berhubungan dengan terjadinya suatu depresi dengan insiden 20/1000. Demikian juga sebaliknya, sehingga hubungan ini dapat terjadi secara dua arah $[10,11]$. Mengingat kerentanan terhadap self-esteem, stresor psikososial, dampak depresi pada pasien disfungsi ereksi dan sedikitnya penelitian tentang hal tersebut di Indonesia, maka peneliti bermaksud mengadakan penelitian tentang hubungan antara disfungsi ereksi dengan tingkat keparahan gejala depresi melalui peran self-esteem dan stresor psikososial pada pasien disfungsi ereksi di Poli Andrologi RSUD dr.Soetomo Surabaya.

\section{Disfungsi Ereksi}

Menurut European Society for Sexual Medicine disfungsi ereksi adalah ketidakmampuan untuk mencapai atau mempertahankan suatu kondisi ereksi yang cukup, sebagai suatu kepuasan dari aktifitas seksual. Kondisi disfungsi ereksi ini berlangsung minimal selama 3 bulan [12]. Massachusetts Male Aging Study, insiden terjadinya disfungsi ereksi adalah 26 per 1000 pria dalam satu tahun. Angka ini ternyata meningkat sesuai umur, mencapai angka 46 per 1000 pria dalam setahun pada usia 60-69 tahun. Suatu penelitian di Asia yang dilakukan sejak tahun 19862006 mengatakan prevalensi disfungsi ereksi di Asia sendiri antara $2-88 \%$, Filipina memiliki prevalensi tertinggi sebesar 33\%, Thailand 29\%, Malaysia 28\%, Korea 18\%, Jepang $13 \%$, Indonesia $11 \%$ dan terendah Singapura $2 \%$ [2]. Kondisi disfungsi ereksi dapat disebabkan oleh berbagai faktor organik seperti vaskuler, anatomi, hormonal, neurogenik, terpapar suatu zat atau obat serta faktor psikologis bahkan kombinasi dari keduanya [13].

\section{Self-Esteem}

William James menemukan konsep self-esteem yang mengatakan definisi self-esteem adalah suatu apresiasi atau penghargaan terhadap diri sendiri, dan hal ini terkait perasaan dan emosi. Smelser (1989) menyatakan bahwa komponen self-esteem adalah kognitif, afektif serta unsurunsur elemen evaluasi lainnya [14]. Faktor-faktor yang mempengaruhi self-esteem yaitu: pola asuh, faktor lingkungan dan faktor nilai (values) yang terdiri dari nilai sosial, nilai pribadi serta gender [15].

\section{Stresor Psikososial}

Girdano (2005) mengatakan stres psikososial (psychosocial stress) adalah stres yang diakibatkan oleh tekanan yang terkait kondisi sosial di sekitarnya. Hal yang bisa menimbulkan stres psikososial adalah perubahan dalam hidup seperti kondisi ekonomi, pekerjaan, masalah 
dengan pasangan dan lain-lain. Stresor dibagi menjadi 2 bagian besar: stresor internal (akibat proses maladaptasi pikiran dan tubuh terhadap stresor) dan stresor eksternal yang terdiri: fisik, biologi, sosial [16]. Pada beberapa pria, stres psikososial yang diakibatkan oleh disfungsi ereksi dapat menyebabkan kecenderungan depresi. Reaksi awal pada pria dengan disfungsi ereksi umumnya adalah emaskulasi, suatu perasaan seperti dikebiri atau dilemahkan secara seksual, karena dirinya tidak mampu memuaskan pasangan mereka [17].

\section{Depresi}

Depresi dalam bidang Psikiatri digunakan untuk menyatakan keadaan mood yang abnormal yang sering diartikan sebagai ketidakbahagiaan, kesedihan maupun kesengsaraan. Gejala utama dari depresi adalah: mood depresif, kehilangan minat, kemauan dan kegembiraan serta berkurangnya energi sehingga nampak mudah lelah [18]. Etiologi depresi: faktor biologi, genetik, riwayat depresi sebelumnya, faktor kepribadian, riwayat obat-obatan [19].

\section{METODE PENELITIAN}

Penelitian ini merupakan penelitian analitik observasional yang bersifat cross sectional, untuk menganalisis hubungan antara disfungsi ereksi dengan tingkat keparahan gejala depresi melalui peran self-esteem dan stresor psikososial. Subyek penelitian adalah pria yang mengalami disfungsi ereksi penderita di Poli Andrologi RSUD Dr. Soetomo Surabaya, periode bulan MeiDesember 2016 yang memenuhi kriteria inklusi: usia $\geq 40$ tahun, pasien disfungsi ereksi sudah menikah, tamat SD, memahami Bahasa Indonesia lisan dan tulisan, bersedia ikut dengan menandatangani informed consent. Kriteria ekslusi: menderita psikotik yang tidak memungkinkan menjawab kuesioner secara obyektif. Kuesioner disfungsi ereksi menggunakan The International Index of Erectile Dysfunction-5, kuesioner self-esteem Rosenberg, stresor psikososial menggunakan kuesioner Social Readjustment Rating Scale Holmes \& Rahe, gejala depresi menggunakan kuesioner Beck Depression Inventory.

\section{HASIL PENELITIAN}

Dari jumlah subyek penelitian 43 orang, sebanyak 2 orang menolak mengikuti penelitian, 3 lainnya tidak memenuhi kriteria inklusi, sehingga total subyek yang memenuhi syarat sebanyak 38 orang.

Tabel 1 Karakteristik Demografi Subyek Penelitian

\begin{tabular}{|c|c|c|}
\hline Variabel & Frekuensi & Persentase $(\%)$ \\
\hline $\begin{array}{c}\text { Usia (tahun) } \\
40-49 \\
50-59 \\
60-69 \\
70-79\end{array}$ & $\begin{array}{l}13 \\
14 \\
9 \\
2\end{array}$ & $\begin{array}{c}34,2 \\
36,8 \\
23,7 \\
5,3\end{array}$ \\
\hline $\begin{array}{c}\text { Agama } \\
\text { Budha } \\
\text { Islam } \\
\text { Kristen }\end{array}$ & $\begin{array}{c}1 \\
34 \\
3\end{array}$ & $\begin{array}{c}2,63 \\
89,47 \\
7,89\end{array}$ \\
\hline $\begin{array}{c}\text { Pendidikan } \\
\text { SMP } \\
\text { SMA } \\
\text { Sarjana }\end{array}$ & $\begin{array}{c}4 \\
18 \\
16\end{array}$ & $\begin{array}{l}10,5 \\
47,4 \\
42,1\end{array}$ \\
\hline $\begin{array}{c}\text { Pekerjaan } \\
\text { Pensiunan } \\
\text { PNS } \\
\text { Swasta }\end{array}$ & $\begin{array}{c}7 \\
7 \\
24\end{array}$ & $\begin{array}{l}18,4 \\
18,4 \\
63,2\end{array}$ \\
\hline $\begin{array}{c}\text { Pendapatan } \\
\text { < } 1 \text { Juta } \\
1 \text { - 3 Juta } \\
>3 \text { Juta } \\
\end{array}$ & $\begin{array}{c}7 \\
14 \\
17\end{array}$ & $\begin{array}{l}18,4 \\
36,8 \\
44,7\end{array}$ \\
\hline $\begin{array}{c}\text { Jumlah anak } \\
\leq 2\end{array}$ & 12 & 31,57 \\
\hline
\end{tabular}




\begin{tabular}{|c|c|c|}
\hline$>2$ & 26 & 68,43 \\
\hline Bekerja & 19 & 50 \\
Ya & 19 & 50 \\
Tidak & 18 & \\
\hline Pendapatan Istri & 4 & 47,4 \\
Tidak berpenghasilan & 9 & 10,5 \\
< Juta & 7 & 23,7 \\
1 - 3 Juta & 18,4 \\
>3 Juta & 38 & 100 \\
\hline
\end{tabular}

Tabel 2 Hubungan Disfungsi Ereksi dengan Self-Esteem

\begin{tabular}{|l|l|c|c|c|}
\hline \multicolumn{2}{|c|}{} & \multicolumn{3}{|c|}{ Self-Esteem } \\
\cline { 3 - 5 } \multicolumn{2}{|c|}{} & & & \\
\multirow{2}{*}{$\begin{array}{l}\text { Disfungsi } \\
\text { Ereksi }\end{array}$} & Disfungsi ereksi ringan & 1 & Normal & Total \\
\cline { 2 - 5 } & & $14,29 \%$ & 11 & 12 \\
& Disfungsi ereksi ringan- & 0 & $35,48 \%$ & $31,58 \%$ \\
\cline { 2 - 5 } & sedang & $0 \%$ & 9 & 9 \\
\cline { 2 - 5 } & Disfungsi ereksi sedang & 3 & $29,03 \%$ & $23,68 \%$ \\
\cline { 2 - 5 } & Disfungsi ereksi berat & $42,86 \%$ & 9 & 12 \\
& & 3 & $29,03 \%$ & $31,58 \%$ \\
\hline \multirow{2}{*}{ Total } & $42,86 \%$ & 2 & 5 \\
& & 7 & $31,45 \%$ & $13,16 \%$ \\
\cline { 3 - 5 } & & $18,42 \%$ & $81,58 \%$ & $100 \%$ \\
\hline
\end{tabular}

Korelasi Pearson: r: 0,388 p: 0,016

Tabel 3 Hubungan Self-Esteem dengan Tingkat Keparahan Gejala Depresi

\begin{tabular}{|c|c|c|c|c|c|c|}
\hline \multicolumn{2}{|c|}{} & \multicolumn{4}{|c|}{ Tingkat Keparahan Gejala Depresi } & \\
\cline { 3 - 7 } & & $\begin{array}{c}\text { Tidak ada } \\
\text { gejala depresi }\end{array}$ & $\begin{array}{c}\text { Gejala } \\
\text { depresi } \\
\text { ringan }\end{array}$ & $\begin{array}{c}\text { Gejala } \\
\text { depresi } \\
\text { sedang }\end{array}$ & $\begin{array}{c}\text { Gejala depresi } \\
\text { berat }\end{array}$ & \multirow{2}{*}{ Total } \\
\hline \multirow{3}{*}{ Self Esteem } & Normal & 7 & 12 & 10 & 2 & 7 \\
\cline { 3 - 7 } & \multirow{2}{*}{ Rendah } & $22,58 \%$ & $38,71 \%$ & $32,26 \%$ & $6,45 \%$ & $18,42 \%$ \\
\cline { 3 - 7 } & $14,29 \%$ & $28,57 \%$ & $28,57 \%$ & $28,57 \%$ & $81,58 \%$ \\
\hline \multicolumn{2}{|c|}{ Total } & 8 & 14 & 12 & 4 & 38 \\
\cline { 3 - 7 } & $21,05 \%$ & $36,84 \%$ & $31,58 \%$ & $10,53 \%$ & $100 \%$ \\
\hline
\end{tabular}

Korelasi Pearson: r: 0,259 p: 0,116

Dari analisis tersebut (Tabel 2) subyek penelitian dengan disfungsi ereksi sedang dan berat, self-esteem yang rendah masing-masing 42,86\%. Karena $\mathrm{p}<0,05$ maka didapatkan disfungsi ereksi berhubungan secara bermakna dengan self-esteem pada subyek penelitian. Skor disfungsi ereksi yang rendah maka makin tinggi derajat disfungsi ereksi, skor self-esteem yang tinggi maka makin tinggi derajat self-esteem. Sehingga makin tinggi derajat disfungsi ereksi maka makin rendah self-esteem subyek penelitian.

Pada analisis tersebut (Tabel 3) subyek penelitian dengan self-esteem yang rendah, gejala depresi ringan, sedang dan berat masing-masing sebesar 28,57\%. Karena p>0,05 maka didapatkan bahwa self-esteem tidak berhubungan dengan tingkat keparahan gejala depresi pada subyek penelitian.

Tabel 4 Hubungan Stresor Psikososial dengan Tingkat Keparahan Gejala Depresi

\begin{tabular}{|c|c|c|c|c|c|c|}
\hline \multirow{2}{*}{} & \multicolumn{3}{|c|}{ Tingkat Keparahan Gejala Depresi } & \multirow{2}{*}{ Total } \\
\cline { 3 - 7 } & $\begin{array}{c}\text { Tidak } \\
\text { ada } \\
\text { gejala } \\
\text { depresi }\end{array}$ & $\begin{array}{c}\text { Gejala } \\
\text { depresi } \\
\text { ringan }\end{array}$ & $\begin{array}{c}\text { Gejala } \\
\text { depresi } \\
\text { sedang }\end{array}$ & $\begin{array}{c}\text { Gejala } \\
\text { depresi } \\
\text { berat }\end{array}$ & \\
\hline $\begin{array}{c}\text { Stresor } \\
\text { Psikososial }\end{array}$ & $\begin{array}{c}\text { Tidak } \\
\text { stres }\end{array}$ & 6 & 5 & 3 & 0 & 14 \\
\cline { 3 - 7 } & & $42,86 \%$ & $35,71 \%$ & $21,43 \%$ & $0,0 \%$ & $36,84 \%$ \\
\hline
\end{tabular}




\begin{tabular}{|c|c|c|c|c|c|c|}
\hline & \multirow{2}{*}{$\begin{array}{l}\text { Stres } \\
\text { ringan }\end{array}$} & 0 & 4 & 0 & 1 & 5 \\
\hline & & $0 \%$ & $80,0 \%$ & $0,0 \%$ & $20,0 \%$ & $13,16 \%$ \\
\hline & \multirow{2}{*}{$\begin{array}{l}\text { Stres } \\
\text { sedang }\end{array}$} & 1 & 4 & 5 & 1 & 11 \\
\hline & & $9,09 \%$ & $36,36 \%$ & $45,45 \%$ & $9,09 \%$ & $28,95 \%$ \\
\hline & \multirow{2}{*}{$\begin{array}{l}\text { Stres } \\
\text { berat }\end{array}$} & 1 & 1 & 4 & 2 & 8 \\
\hline & & $12,5 \%$ & $12,5 \%$ & $50,0 \%$ & $25,0 \%$ & $21,05 \%$ \\
\hline \multirow{2}{*}{\multicolumn{2}{|c|}{ Total }} & 8 & 14 & 12 & 4 & 38 \\
\hline & & $21,05 \%$ & $36,84 \%$ & $31,58 \%$ & $10,53 \%$ & $100 \%$ \\
\hline
\end{tabular}

Korelasi Pearson: r: 0,503 p: 0,001

Tabel 5 Hubungan Disfungsi Ereksi dengan Tingkat Keparahan Gejala Depresi

\begin{tabular}{|c|c|c|c|c|c|}
\hline \multirow{2}{*}{} & \multicolumn{3}{|c|}{ Tingkat Keparahan Gejala Depresi } & \\
\cline { 2 - 6 } & $\begin{array}{c}\text { Tidak ada } \\
\text { gejala } \\
\text { depresi }\end{array}$ & $\begin{array}{c}\text { Gejala } \\
\text { depresi } \\
\text { ringan }\end{array}$ & $\begin{array}{c}\text { Gejala } \\
\text { depresi } \\
\text { sedang }\end{array}$ & $\begin{array}{c}\text { Gejala } \\
\text { depresi berat }\end{array}$ & Total \\
\hline Disfungsi ereksi ringan & 2 & 9 & 1 & 0 & 12 \\
\cline { 2 - 6 } & $25 \%$ & $64,29 \%$ & $8,33 \%$ & $0 \%$ & $31,58 \%$ \\
\hline Disfungsi ereksi ringan-sedang & 4 & 1 & 4 & 0 & 9 \\
\cline { 2 - 6 } & $50 \%$ & $7,14 \%$ & $33,33 \%$ & $0 \%$ & $23,68 \%$ \\
\hline Disfungsi ereksi sedang & 2 & 3 & 6 & 1 & 12 \\
\multirow{2}{*}{ Disfungsi ereksi berat } & $25 \%$ & $21,43 \%$ & $50 \%$ & $8,33 \%$ & $31,58 \%$ \\
\cline { 2 - 6 } & 0 & 1 & 1 & 3 & 5 \\
Total & 8 & 14 & 12 & 4 & 38 \\
\cline { 2 - 6 } & $21,05 \%$ & $36,84 \%$ & $31,58 \%$ & $10,53 \%$ & $100 \%$ \\
\hline
\end{tabular}

Korelasi Pearson: r: $-0,559$ p: 0,000

Dari analisis tersebut (Tabel 4) subyek penelitian dengan stres ringan, gejala depresi ringan sebesar $80,0 \%$, stres sedang didapatkan gejala depresi sedang sebesar $45,45 \%$, stres berat didapatkan gejala depresi sedang sebesar 50,0\%. Karena $\mathrm{p}<0,05$ maka didapatkan hubungan antara stresor psikososial dengan tingkat keparahan gejala depresi pada subyek penelitian. Skor stresor psikososial yang tinggi makin tinggi stresor psikososial, skor gejala depresi yang tinggi maka makin tinggi tingkat keparahan gejala depresi. Sehingga makin tinggi stresor psikososial, makin tinggi pula tingkat keparahan gejala depresi subyek penelitian.

Dari analisis tersebut (Tabel 5) subyek penelitian dengan disfungsi ereksi ringan didapatkan gejala depresi ringan sebesar 64,29\%, disfungsi ereksi sedang didapatkan gejala depresi sedang sebesar 50,0\%, disfungsi ereksi berat didapatkan gejala depresi berat sebesar 75,0\%. Karena p<0,05 maka didapatkan hubungan antara disfungsi ereksi dengan tingkat keparahan gejala depresi pada subyek penelitian. Skor disfungsi ereksi yang rendah makin tinggi derajat disfungsi ereksi, skor gejala depresi yang tinggi maka makin tinggi tingkat keparahan gejala depresi. Sehingga makin tinggi derajat disfungsi ereksi, maka makin tinggi pula tingkat keparahan gejala depresi yang dialami subyek penelitian.

\section{DISKUSI}

\section{Karakteristik Data dan Subyek Penelitian}

Berdasarkan umur, studi The Massachusetts Male Aging Study mengatakan prevalensi disfungsi ereksi akan bertambah sesuai dengan pertambahan umur [1], namun pada penelitian ini tidaklah demikian, hal ini disebabkan pada subyek yang lebih tua akan cenderung terkait kultur menerima dan pasrah, menganggap kondisi itu sebagai sesuatu yang wajar. Aspek lainnya dikarenakan masalah ekonomi sehingga mereka jarang mencari pengobatan [2].

Berdasarkan data riwayat penyakit penyerta seperti diabetes melitus dan hipertensi, hal ini sesuai dengan patofisiologi dan penyebab disfungsi ereksi bahwa disfungsi ereksi dapat disebabkan kondisi organik [13]. Studi lain juga menyatakan obat-obatan seperti obat anti hipertensi seperti calcium channel blocker, beta-blocker, diuretik berhubungan dengan terjadinya disfungsi ereksi [20]. Ditemukan dalam studi ini distribusi disfungsi ereksi yang sebagian besar subyek mengalami disfungsi ereksi ringan hingga sedang hal ini diduga terkait lama mengalami gejala 
disfungsi ereksi, semakin lama akan memperberat timbulnya gejala tersebut [11]. Berdasarkan distribusi selfesteem sebagian besar subyek memiliki self-esteem yang normal $(81,6 \%)$. Sehingga orang yang dengan self-esteem normal akan cenderung bertindak lebih asertif dibandingkan mereka dengan self-esteem rendah yang cenderung menghindar dan enggan mencari pengobatan [21]. Distribusi stresor psikososial juga didapatkan sebagian subyek mengalami stres $(63,2 \%)$ yang mayoritas mengalami kesulitan dalam hal seksual dengan pasangan serta terkait kondisi medis atau jatuh sakit yang memang sesuai dialami oleh subyek penelitian [22]. Terkait distribusi tingkat keparahan gejala depresi pada studi ini ditemukan sebagian besar subyek mengalami gejala depresi $(78,9 \%)$ dari derajat ringan hingga berat. Hal ini juga sesuai dengan studi sebelumnya di Jepang yang mengatakan bahwa gejala depresi merupakan salah satu gejala psikologis yang sering ditemukan pada pria disfungsi ereksi [23].

\section{Hubungan Antara Disfungsi Ereksi dengan Self-Esteem}

Terdapatnya hubungan antara disfungsi ereksi dengan self-esteem dapat disebabkan oleh budaya orang timur yang cenderung beranggapan bahwa kelanggengan suatu rumah tangga ditentukan oleh faktor keberhasilan suami bisa membahagiakan istri secara seksual. Pada suami yang mengalami disfungsi ereksi cenderung menutup diri, kurang perkasa bahkan malu untuk mencari pengobatan sehingga kondisi disfungsi ereksinya bertambah buruk sehingga terjadi low self-esteem [5], [6].

\section{Hubungan Antara Self-Esteem dengan Tingkat}

\section{Keparahan Gejala Depresi}

Tidak terdapatnya hubungan antara self-esteem dengan tingkat keparahan gejala depresi dapat disebabkan oleh karena subyek penelitian yang memiliki self-esteem rendah masih mendapatkan support dari pasangan berupa reassurance bahwa kondisi yang di alami subyek adalah sesuatu yang wajar dengan bertambahnya usia [2]. Dari data demografi subyek juga sebagian besar masih mempunyai pekerjaan $(81,6 \%)$ dan penghasilan diatas upah minimum rata-rata $(81,5 \%)$, sehingga kekurangan dari diri subyek tersebut bisa dialihkan dengan bekerja keras dan penghasilan yang membantu menguatkan self-esteem. Secara nilai sosial subyek pada penelitian ini rata-rata sudah memiliki anak bahkan mayoritas $\geq 2$ sehingga subyek mempersepsikan bahwa jika sudah mempunyai anak maka dirinya dan pasangan sudah merasa lengkap dalam berumahtangga [15].

\section{Hubungan Antara Stresor Psikososial dengan Tingkat Keparahan Gejala Depresi}

Berdasarkan penelitian di Finland menunjukan adanya hubungan yang bermakna antara stresor psikososial terhadap kondisi fisik dan psikis seseorang sehingga nantinya akan timbul gejala depresi (Makikangas \& Kinnunen, 2003). Terdapatnya hubungan antara stresor psikososial dengan tingkat keparahan gejala depresi pada subyek penelitian dapat disebabkan kondisi disfungsi ereksi yang tidak tertangani dengan baik ditambah stresor psikososial lain serta koping maladaptif dapat menyebabkan distres yang semakin membebani sehingga memperburuk gejala depresi [8].

Hubungan Antara Disfungsi Ereksi dengan Tingkat Keparahan Gejala Depresi Melalui Peran Self-Esteem dan Stresor Psikososial

Berdasarkan analisis korelasi, pada penelitian ini terdapat hubungan antara disfungsi ereksi dengan tingkat keparahan gejala depresi secara langsung namun dalam perjalanannya, disfungsi ereksi berhubungan dengan selfesteem, tapi self-esteem sendiri tidak berhubungan dengan tingkat keparahan gejala depresi. Disfungsi ereksi tidak berhubungan dengan stresor psikososial, namun stresor psikososial sendiri berhubungan dengan gejala depresi. Sehingga dapat dikatakan pada penelitian ini terdapat hubungan antara disfungsi ereksi dengan tingkat keparahan gejala depresi secara langsung namun tidak melalui melalui peran self-esteem dan stresor psikososial. Hal ini dapat terjadi disebabkan kultur atau budaya Asia yang cenderung tertutup dibandingkan budaya barat yang lebih terbuka, serta pengaruh agama yang mengajarkan seseorang cenderung untuk pasrah dan menerima kondisi tersebut [2], sedangkan pada subyek penelitian cenderung ditutupi apalagi pasangannya jarang langsung mengeluh dan menganggap kondisi disfungsi ereksi adalah hal yang biasa sesuai pertambahan umur, ditunjang pula oleh subyek masih bekerja dan mempunyai pendapatan sehingga self-esteem tidak berpengaruh terhadap gejala depresi. Alasan lainnya adalah disfungsi ereksi adalah suatu kelemahan kondisi 
yang fisik tidak nampak dari luar, subyek penelitian masih merasa belum terganggu self-esteem nya [24]. Stresor psikososial justru dikatakan berhubungan secara bermakna dengan gejala depresi, hal ini dapat disebabkan stresor psikososial yang makin bertumpuk, mekanisme koping yang kurang baik dan kronis terjadi distres sehingga timbul gejala depresi [8].

\section{Keterbatasan Penelitian}

Usia subyek penelitian $\geq 40$ tahun berdampak pria muda dibawah umur tersebut tidak terseleksi, padahal kondisi disfungsi ereksi akibat psikogenik banyak terjadi pada usia yang lebih muda. Tidak dibedakan secara jelas subyek penelitian yang terseleksi sudah mengikuti terapi (efektifitas terapi) atau belum mengikuti terapi terhadap kondisi disfungsi ereksinya. Tidak dibedakan secara jelas subyek yang memiliki riwayat dan terapi psikiatri sebelumnya. Latar belakang budaya dan spiritual yang membuat adanya jawaban subyek yang cenderung denial, faking good atau jawaban aman. Penelitian ini tidak meneliti kepribadian subyek penelitian yang dapat berpengaruh pada mekanisme koping dalam menghadapi sakit, serta tidak ditelitinya mengenai pola asuh, faktor nilai dan faktor lingkungan yang dapat berpengaruh terhadap self-esteem.

\section{KESIMPULAN}

Terdapat hubungan antara disfungsi ereksi dengan tingkat keparahan gejala depresi secara langsung tanpa melalui peran self-esteem dan stresor psikososial. Terdapat hubungan antara disfungsi ereksi dengan self-esteem yang artinya makin tinggi disfungsi ereksi maka makin rendah self-esteem yang dialami subyek penelitian. Tidak terdapat hubungan antara derajat self-esteem dengan tingkat keparahan gejala depresi. Terdapat hubungan antara stresor psikososial dengan tingkat keparahan gejala depresi, yang artinya makin tinggi stresor psikososial maka terjadi peningkatan tingkat keparahan gejala depresi yang dialami subyek penelitian.

\section{SARAN}

Perlu dilakukan studi lanjutan untuk membuktikan bahwa ada faktor-faktor lain yang dapat mempengaruhi selfesteem dan tingkat keparahan gejala depresi. Dapat menggunakan populasi yang lebih luas terkait etiologi, sehingga disfungsi ereksi psikogenik yang banyak terdapat pada pria di usia muda dapat juga tertangani dengan baik, serta instrumen yang lebih spesifik dan sesuai dengan masyarakat Indonesia mengingat disfungsi ereksi masih dianggap sesuatu sensitif sehingga cenderung untuk ditutupi. Kerjasama multidisipliner antar departemen yang baik dan berkesinambungan diperlukan, agar penanganan bisa terlaksana secara holistik.

\section{DAFTAR PUSTAKA}

[1] Farca Z.E., Velez F.V., Eransus M.C., Bravo O.A., Tseng L.J., Stecher V.J., "Self-esteem, confidence and relationship satisfaction in men with erectile dysfunction: a randomized, parallel-group, double blind, placebo-controlled study of sildenafil in mexico," Int. J. Impot. Res., vol. 20, pp. 402-408, 2008.

[2] Park K., Hwang E.U., Kim S.O, "Prevalence and medical management of erectile dysfunction in asia," Asian J. Androl., vol. 13, pp. 543-549, 2011.

[3] Prasad K.N., Kumar P.S., Poovitha, "Perception about penis length, penile erection and quantity of semen among young adult men pondicherry, indiacommunity based cross sectional study," Sch. J. Appl. Med. Sci., vol. 2(4A), pp. 1214-1219, 2014.

[4] Pastuzak A.W., Badhiwala N., Lipshultz L., Khera M., "Depression is correlated with the psychological and pshysical aspects of sexual dysfunction in men," Int. J. Impot. Res., vol. 25, pp. 194-199, 2013.

[5] Fatt K.Q, "Erectile dysfunction and quality of life in Nunes K (ed)," in Erectile Dysfunction DiseaseAssociated Mechanism and Novel Insight into Therapy, Rijeka, Croatia: InTech Publisher, 2012.

[6] Sowislo J.F., Orth U., "Does low self-esteem predict depression and anxiety? a meta-analysis of longitudinal studies," Psychol. Bull., vol. 139 (1), pp. 213-40, 2012. 
[7] Udo I.A., Udoh S.B., "Psychosocial factors associated with erectile dysfunction in the niger delta region of nigeria," J. Fam. Med. Med. Sci. Res., vol. 4, pp. 1-4, 2015.

[8] Smith J.F, "Sexual function and depressive symptoms among male north american medical students," J. Sex. Med., vol. 7, pp. 3909-17, 2010.

[9] Sumarni D.W., Maulina D.S., "Pengaruh stresor psikososial terhadap depresi dan gangguan kesehatan reproduksi guru perempuan sekolah dasar negeri," Ber. Kedokt. Masy., vol. 22, pp. 107-114, 2006.

[10] Rajkumar P.R., Kumaran K.A, "Depression and anxiety in men with sexual dysfunction: a retrospective study," Compr. Psychiatry, vol. 60, pp. 114-118, 2015.

[11] Shiri R., Koskimaki J., Tammela L.J.T., Hakkinen J., Auvinen A., Hakama M., "Bidirectional relationship between depression and erectile dysfunction," $J$. Urol., vol. 177, pp. 669-673, 2007.

[12] Kirana P.S., Porst H., "Erectile dysfunction in Kirana P.S., Tripodi F., Reisman Y., Porst H., (eds)," in The EFS and ESSM Syllabus of Clinical Sexology, $1^{\text {st }}$ edition., Amsterdam: Medix Publisher, 2013.

[13] Heidelbaugh J.J \& Arbor A, "Management of erectile dysfunction," Am. Fam. Physician, vol. 81, pp. 305312, 2010.

[14] Guindon M.H, "What is self-esteem in Guindon (ed)," in Self-Esteem Across the Lifespan: Issue and Intervention, LLC, New York: Taylor and Francis Group, 2010.

[15] Mruk C.J, "The crucial issue of defining self-esteem in Mruk C.J (ed)," in Self-esteem research, theory and practice: toward a positive psychology of self- esteem 3rd ed., New York: Springer Publishing Company, Inc., 2006.

[16] Girdano D.A., Dusek D.E., Everly G.S., Controlling Stress and Tension, $6^{\text {th }}$ ed. Boston: Allyn \& Bacon Press, 2001.

[17] Dean J., Boer B.J., Graziottin A., Hatzichristou D., Heaton J., Tailor A, "The role of erection hardness in determining erectile dysfunction treatment outcome," Eur. Urol. Suppl., vol. 5, pp. 767-772, 2006.

[18] Lam W.R., Mok H., Depression, Oxford Psychiatry Library $1^{\text {st }}$ ed. New York: Oxford University Press Inc, 2008.

[19] Saddock B.J, Saddock V.A., "Mood disorder in (ed) Kapplan and Saddock," Synopsis of Psychiatry $10^{\text {th }}$ ed., London: William and Wilkins, 2007, pp. 527-562.

[20] McVary T.K, "Erectile dysfunction,” N. Engl. J. Med., vol. 357, pp. 2472-2481, 2007.

[21] Donnellan M.B., Trzesniewski K.H., Robins R.W., Moffitt T.E., Caspi A, "Low self-esteem is related to aggression, antisocial behavior, and delinquency," Psychol. Sci. J., vol. 16, no. 4, pp. 328-335, 2005.

[22] Shamloul R \& Ghanem H, "Erectile dysfunction," Seminar, vol. 381, pp. 153-165, 2013.

[23] Nicolosi E., Moreira E.D., Villa M., Glasser D.B, “A population study of the association between sexual function, sexual satisfaction and depresive symptoms in men," J. Affect. Disord., vol. 82, pp. 235-243, 2004.

[24] Heatherton T.F \& Wyland C.L, "Assessing selfesteem in Lopez S \& Snyder R (ed)," in Assessing Positive Psychology, Washington DC: Washington Press, 2003 